\title{
The Place of Ethics in Ireland and Elsewhere
}

PATTY A GRAY

National U Ireland Maynooth

Thomas STRONG

National U Ireland Maynooth

How is an ethnographic sensibility helpful in considering the ethical implications of anthropological research on human subjects? The terms "ethics" and "the ethical" circulate globally in powerful and consequential ways; some anthropologists have taken the concepts themselves to be domains of description and analysis, making them part of anthropology's on-going conversation about its own forms of inquiry.

Our experience as US-trained anthropologists working in the European Union teaches us that an ethnographic sensibility about the domain of ethics is not only intellectually interesting, but professionally necessary in a world where scholars find themselves working transnationally. For example, while we are familiar with the common criticism of US-based anthropologists about IRB mission creep, in the European context we have been surprised either by a lack of formal ethical review or by the apparent newness of the discussion about how such review should be administered.

Our response to this paradoxical situation is to recognize what Petryna (American Ethnologist 2005) calls "ethical variability": descriptive precision with regard to the standards and practices of actually existing normative regimes in any given place. This helps us avoid the risk that, socialized into a particular style of bureaucratic oversight, we may misread local ethical discussions and inadvertently import US-style worries into contexts where they are not salient.

We are both new to the Republic of Ireland, where we teach in the only department of anthropology in the state. Unlike the US, in Ireland there is no federal regulation driving the development of institutional review procedures; but there is a strong will to create a workable system of ethical oversight for research, and a refreshing openness to new ideas and approaches. Our university recently created a subcommittee of the University Ethics Committee to deal exclusively with social research, and one of us was appointed its first chair. This seems a rare opportunity to bring an ethnographic sensibility to the collaborative crafting of a locally salient approach to institutional ethical review.

To learn about the ethical problems of Ireland-based social research, we formed a Working Group for CrossDisciplinary Dialogue on Research Ethics. We wanted to forestall a narrow equation of research ethics with formal review, since our conviction is that research is ethical when researchers themselves have internalized ethical principles through both formal training and informal discussion. We felt the working group would pull the centre of gravity in the formative discussion on research ethics away from the official context and toward the community of colleagues in our university faculties. To kick off the working group, in November

2010 we held a roundtable discussion on social research ethics in Ireland. We invited scholars from the US, UK and Ireland to examine changing or emerging norms around ethics in social research. Here we highlight how their contributions show the emergence of a descriptive sensibility in respect to the existing practice of ethics in particular places.

Casting an ethnographic eye on how different disciplines in the US configure styles of inquiry, Rena Lederman (anthropology, Princeton U) showed ways that ethics and epistemology are often closely linked, as when different assumptions inform the tactical use of deception in relation to research aims in psychology and anthropology. Christine Milligan (geography, Lancaster $U$ ) reviewed the history of ethics "regs" in Britain and zeroed in on difficulties that emerge when ethics committees review not just ethics but also the putative scientific validity of research design. Finally, Jennifer Schweppe, who lectures in law at the University of Limerick (UL), reviewed the history of formal ethics review of social research in Ireland and at UL, and spoke about specific concerns of disadvantaged communities in Ireland that see themselves as persistently surveilled by the inquiring gaze of researchers.

We viewed the roundtable as an opportunity both to advance discussion and to tune ourselves in to local dialogue about what ethics comprises. The experience reinforced our conviction that specific histories of disciplines, controversies and governing bodies need to be analyzed and understood in particular places. Experience in cross-cultural research notwithstanding, this is a lesson anthropologists can afford to learn time and again. We hope this and future such events will help shape a reflexive attitude toward the ethics of conduct in anthropological research based at universities in Ireland.

Thomas Strong and Patty A Gray are lecturers (analogous to associate professor) in the anthropology department at the National University of Ireland Maynooth. Both have spent time in other European academic contexts-Strong in Finland and Gray in Germany and Russia. Strong has conducted research in Papua New Guinea and East Africa, and is currently working on the social ramifications of longterm survival with HIV. Gray's current work concerns Russia's emergence as a donor of official development assistance and Irish charity and aid workers who target Eastern Europe.

Liam Frink is contributing editor of Ethical Currents, the AN column of the AAA Committee on Ethics. He may be contacted at lfrink@unlv.edu. W

Want to see the RACE Project? Find the tour schedule at www.understandingrace.org/about/tour.html
BERMAN FOUNDATION

DISSERTATION FELLOWSHIPS

in Support of Research in the

Social Scientific Study of the

Contemporary American Jewish Community

Directed by the

Association for Jewish Studies

The Berman Fellowships-

two awards of $\$ 16,000$

each-will support doctoral

work in the social scientific

study of the North American

Jewish community during the

20 I I-20 I 2 academic year.

\section{Application Deadline:}

\section{APRIL 7, 20 I I}

\section{Support for this project is} generously provided by the Mandell L. and Madeleine $H$.

Berman Foundation.

For further information, please visit the AJS website at www.ajsnet.org/berman.htm. 